\title{
Chemical Control of Margarodes prieskaensis (Jakubski) (Coccoidea: Margarodidae) on Grape-vines
}

\author{
C.A. de Klerk \\ Submitted for publication: December 1986 \\ Accepted for publication: February 1987 \\ Keywords: Margarodes, chemical control, grape-vines.
}

Viticultural and Oenological Research Institute, Private Bag X5026, 7600 Stellenbosch, Republic of South Africa.

\begin{abstract}
Hexachlorobutadiene was applied with hand soil - injector guns as well as on commercial scale in two established vineyards at a rate of $12 \mathrm{~m} l / \mathrm{m}^{2}$ to control Margarodes prieskaensis (Jakubski). Adult females as well as male pre-pupae and pupae were effectively controlled. Best results were obtained with an application after harvest during March. Although the cyst stage was not affected, applications during two consecutive years could effectively control the pest. Dichloropropene, aldicarb, fenamiphos, carbofuran and oxamyl were found to be ineffective in the control of $M$. prieskaensis.
\end{abstract}

Numerous species of the genus Margarodes (ground pearls) occur on a wide range of host plants almost throughout the world. Grape-vine infesting species have, however, only been reported from North and South America and from South Africa. Margarodes vitis (Phillipi), one of the three American species found on vines, is of great economic importance. Severe damage is caused by this species especially in Chile where approximately 600 ha of vineyards were found to be infested (Fauré \& Pinto, 1959). The other two known vine infesting species are Margarodes meridionalis Morrison in California and Margarodes brasiliensis Hempel from South America (Jakubski, 1965). The extent of the damage caused by these two species is unknown but according to Barnes, Asch \& Deal (1954) $M$. meridionalis is considered to be a potential threat.

Ten species of Margarodes are presently known to occur in South Africa, five of which infest vine roots (De Klerk, 1983; De Klerk, Ben-Dov \& Giliomee 1982a, 1982b, \& 1983). These species are endemic to South Africa and have not as yet been reported from any other country.

According to De Klerk (1985), margarodes occurs in most of the major vine growing areas of South Africa and all vine infesting species are of economic importance. Margarodes is an increasingly serious pest in the Orange River (Northern Cape) and Olifants River (North Western Cape) irrigation areas where numerous vineyards are infested, resulting in vines dying in patches. The problem has also become serious in the Western Cape, especially in the Malmesbury area where approximately 86 ha are infested and several vineyards have been completely destroyed (De Klerk, 1985).

Margarodes attacks the vine roots, and aboveground symptoms of infested vines resemble those of phylloxera infested vines. The first symptom is a gradual decline in vigour which becomes more severe with time, the shoots becoming shorter and thinner, with smaller leaves. Later, one or more arms of the vine and finally the whole vine dies. The duration of this process varies greatly but vines could be killed within four years. Damage usually starts in patches which gradually become larger, probably due to slow migration of larvae and adult females in the soil. In the event of a severe and uniform infestation the whole vineyard shows a decline in vigour. No characteristic galls or other symptoms are found on the roots as in the case of phylloxera.

At present no pesticide is registered for the control of margarodes in vineyards, and no rootstock resistant to this pest is known. According to De Klerk (1975) margarodes attacks three of the best phylloxera resistant rootstocks commonly used in South Africa, viz. 99 Richter, 101-14 Mgt and Vitis rupestris (var. du Lot). It would, therefore, seem that an infestation is permanent and that infested land may become unsuitable for economic grape-vine cultivation.

One of the main vine infesting species is Margarodes prieskaensis (Jakubski). It occurs at Hopetown, Prieska, Groblershoop, Upington, Keimoes and Kakamas in the Orange River irrigation area, Northern Cape (De Klerk, 1985). This species was first described as Sphaeraspis prieskaensis Jakubski (De Klerk et al., 1982a).

According to Du Toit (1975) the life cycle of $M$. prieskaensis is as follows: Eggs are laid in the vicinity of the vine roots during October and November. After hatching, the young first instar larvae insert their mouthparts into the root tissue, and secrete a waxy material which soon encloses them in a hard pearl-like cyst. Within the cyst the larva moults to become a nymph and the cyst increases in size. The duration of the cyst stage and number of moults of the nymph was not established. Mature cysts can remain inactive in the soil for many years. Adult females emerge from the cysts during July and August and move to just below the soil surface. Male pre-pupae emerge from the cysts during May and June, and pupate about $15 \mathrm{~mm}$ below the soil surface. Winged adult males emerge from the pupae and appear above ground during July and August, at the same time that females appear. When conditions for mating are favourable, the female protrudes her posterior end above the soil surface. This is repeat-

Presented at the 10th congress of the South African Society for Enology and Viticulture, Cape Town 1986.

The author wishes to express his sincere thanks to Mr. Frik Coetzee for making available the experimental vineyards and to Mr Antoine Coetzee and Miss Elisabeth du Toit for technical assistance. 
ed daily till mating occurs. After mating the female burrows down into the soil to lay eggs in the vicinity of the roots.

Because of the seriousness of the margarodes problem, two field trials were conducted at Garieb near Upington in the Orange River irrigation area to determine the effectiveness of certain pesticides for the control of $M$. prieskaensis. In the first trial the pesticides were applied by hand in small experimental plots and in the second trial one chemical was applied on a commercial scale. These trials are reported on in this paper.

\section{MATERIALS AND METHODS}

\section{Hand application:}

The first trial was conducted in an ungrafted Sultanina vineyard with vine spacing $3,6 \mathrm{~m} \times 1,8 \mathrm{~m}$ and trained on a T-trellis as described by Zeeman (1981). The vines were eight years old and flood irrigated. Some vines had already died as a result of high margarodes infestation. The trial consisted of the following treatments:

Untreated control

Hexachlorobutadiene (C46) at $12 \mathrm{ml} / \mathrm{m}^{2}$

Dichloropropene (Telone) at $10 \mathrm{ml} / \mathrm{m}^{2}$

Aldicarb (Temik) $15 \%$ granules (gran.) at $3,3 \mathrm{~g} / \mathrm{m}^{2}$

Fenamiphos (Nemacur) $10 \%$ gran. at $20 \mathrm{~g} / \mathrm{m}^{2}$

Carbofuran (Curaterr) $10 \%$ gran. at $10 \mathrm{~g} / \mathrm{m}^{2}$

Oxamyl (Vydate) $10 \%$ gran. at $10 \mathrm{~g} / \mathrm{m}^{2}$

Each treatment was replicated five times in a randomized block design. Each plot consisted of the area between two rows of five vines each $\left(32 \mathrm{~m}^{2}\right)$. Plots were separated from each other by at least $3,6 \mathrm{~m}$ (row width) and $9 \mathrm{~m}$ in the row. Plots were selected according to poor vine growth and the presence of adult females on the soil surface during August 1982.

Hexachlorobutadiene and dichloropropene were applied with hand soil-injector guns at a depth of $200 \mathrm{~mm}$ with one application per $450 \mathrm{~mm} \times 450 \mathrm{~mm}$ area. The other chemicals were evenly distributed by hand over the whole surface of each plot and incorporated into the top $150 \mathrm{~mm}$ of soil with a rotavator. Treatments were applied in August 1982 just prior to budburst and all plots were flood irrigated on the same day. All treatments were evaluated as follows:

Cysts

During December 1982, four months after treatment, cysts were collected. A ditch, 1,2 m long, $600 \mathrm{~mm}$ wide and $900 \mathrm{~mm}$ deep was dug parallel to the vine row and $300 \mathrm{~mm}$ from the trunk of the vine in the middle of each plot. The excavated soil was examined in the vineyard and all cysts collected were counted in the laboratory. Cysts with an emergence orifice (empty cysts) were discarded. As the majority of live cysts sink in water (De Klerk, Giliomee \& Ben-Dov, 1980), the number of dead cysts was determined using this technique and the mortality percentage was calculated for each plot.

\section{Adult females}

Adult females on the soil surface as well as in the soil to a depth of $150 \mathrm{~mm}$ were counted over an area of $600 \mathrm{~mm} \times 300 \mathrm{~mm}$ in the vineyard. These counts were made at three randomly selected areas per plot during August 1983, 1984 and 1985.

\section{Male pupae and pupae}

The soil from a ditch, $1 \mathrm{~m}$ long, $200 \mathrm{~mm}$ wide and $80 \mathrm{~mm}$ deep, was examined in the vineyard and all prepupae and pupae counted. These counts were made at three randomly selected areas per plot, during June 1983, 1984 and 1985.

\section{Commercial application:}

The second trial was conducted in a heavily infested Sultanina vineyard adjacent to the first trial. The vines were six years old, spaced $3,6 \times 1,8 \mathrm{~m}$, trained on a Ttrellis and flood irrigated. Hexachlorobutadiene was applied according to the standard method for applying liquid nematicides on commercial scale by means of a Doyle apparatus and tractor drawn tiller with tines $500 \mathrm{~mm}$ apart. The chemical was applied at $12 \mathrm{ml} / \mathrm{m}^{2}$ and at a depth of $200 \mathrm{~mm}$ over the whole surface between the rows.

To determine the most effective time of application and the effect of follow-up applications, the chemical was applied during August 1983; August 1983 plus March 1984, and March 1984 in plots consisting of the area between four rows of $50 \mathrm{~m}$ long. Four rows were left untreated as a control. The two plots treated in March 1984, were again treated in March 1985. Because of the extent of the experiment, treatments were not replicated.

The number of adult females was determined as described for hand application and observations were made during August 1984 and August 1985. The number of male pre-pupae and pupae was determined during June 1984 and June 1985 as described for the first trial. Counts were made at five randomly selected areas between the middle rows of each plot and the percentage control per treatment was calculated according to the number of individuals found in the untreated control plot. No observations were made on the cyst stage.

\section{RESULTS AND DISCUSSION}

\section{Hand application:}

\section{Cysts}

The cyst population varied considerably throughout the experimental block and variation of up to $95 \%$ between replicates of even the control plots occurred. Except for a few plots, the number of cysts was very low and in some cases no cysts were found to a depth of $900 \mathrm{~mm}$ (Table 1). Because of these factors no signifi-

TABLE 1

Effect of different pesticides, four months after hand application, on the total number and percentage mortality (figures in brackets) of cysts of Margarodes prieskaensis to a depth of $900 \mathrm{~mm}$ in the soil

\begin{tabular}{|l|r|r|r|rr|r|r|}
\hline \multicolumn{1}{|c|}{} & \multicolumn{5}{|c|}{ Treatment } & \multicolumn{1}{c|}{ I } & \multicolumn{2}{c|}{ II } & \multicolumn{2}{c|}{ III } & IV & Means \\
\hline $\begin{array}{l}\text { Control } \\
\text { Hexachloro- }\end{array}$ & $196(13)$ & $12(40)$ & $45(30)$ & $40(38)$ & $9(83)$ & $60(41)$ \\
butadiene & $20(70)$ & $3(50)$ & $15(40)$ & $1(-)$ & $6(50)$ & $9(53)$ \\
Dichloro- & & & & & & \\
propene & $2(-)$ & $2(-)$ & $1(-)$ & $7(40)$ & $5(75)$ & $3(58)$ \\
Aldicarb & $1(-)$ & $113(33)$ & $21(50)$ & $38(17)$ & $1(-)$ & $35(33)$ \\
Fenamiphos & $7(57)$ & $15(92)$ & $34(21)$ & $0(-)$ & $0(-)$ & $11(57)$ \\
Carbofuran & $6(67)$ & $19(20)$ & $0(-)$ & $16(60)$ & $1(-)$ & $8(49)$ \\
Oxamyl & $32(37)$ & $10(71)$ & $12(89)$ & $6(100)$ & $0(-)$ & $12(74)$ \\
\hline
\end{tabular}

$\star$ No statistical differences $(\mathrm{P}=0,05)$ 
cant differences were found between treatments and the control. With field studies on Margarodes capensis Giard in the Malmesbury area (Western Cape), De Klerk, Giliomee \& Ben-Dov (1982) also found a great variation in the population density of cysts between different vines.

As indicated in Table 1 the natural mortality of cysts in the control plots was very high $(41 \%)$. A high natural mortality rate $(26,5 \%)$ was also found for $M$. capensis (De Klerk et al., 1982). According to these authors dead cysts could remain in the soil without decaying for periods longer than one year and the accumulation of dead cysts during successive years could have contributed to the apparent high mortality. The mortality rate for the different treatments was high and great variation occurred between plots (Table 1). No significant differences were found in mortality between any treatment and the control.

Because of the time-consuming method in determining the number of cysts, and the great variation in population density as well as percentage mortality obtained, no further observations were made on the cysts stage except for the plot that received hexachlorobutadiene in August 1983.

\section{Adult females}

During August 1983, 12 months after application, the number of females in plots treated with hexachlorobutadiene was significantly less than that of the control plots (Table 2). During 1984, 24 months after application, and during 1985, 36 months after application, no statistical differences were found. Therefore the percentage control after 12 months was regarded as reasonably satisfactory, but during the following two years the control was poor. The other pesticides tested gave very little or no control during the first two observation periods and were therefore not evaluated during 1985.

\section{TABLE 2}

Mean number of adult females of Margarodes prieskaensis per plot in successive years after a single hand application with different pesticides. (Percentage control in brackets).

\begin{tabular}{|c|c|c|c|}
\hline \multirow[b]{2}{*}{ Treatment } & \multicolumn{3}{|c|}{ Date of observation } \\
\hline & $\begin{array}{c}1983 \\
12 \text { months after } \\
\text { application }\end{array}$ & $\begin{array}{c}1984 \\
24 \text { months after } \\
\text { application }\end{array}$ & $\begin{array}{c}1985 \\
36 \text { months after } \\
\text { application }\end{array}$ \\
\hline Control & $23(0)$ & $25 \quad(0)$ & $33 \quad(0)$ \\
\hline butadiene & $8^{*}(65)$ & $13(48)$ & $16(52)$ \\
\hline $\begin{array}{l}\text { Dichloro- } \\
\text { propene }\end{array}$ & & $37 \quad(0)$ & - \\
\hline Aldicarb & $15(35)$ & $21(16)$ & - \\
\hline Fenamiphos & $16(30)$ & $25(0)$ & - \\
\hline Carbo & $22(4)$ & $40 \quad(0)$ & - \\
\hline Oxamyl & $20(13)$ & $16(36)$ & - \\
\hline
\end{tabular}

$\star$ Significantly different from the control $(\mathrm{P}=0,05)$

As all females do not emerge from cysts at the same time, it is possible that females that were collected did not have time to die after making contact with the chemical.

During August 1983, 130 adult females collected from plots treated with hexachlorobutadiene and 126 from control plots were therefore kept in the laboratory and the percentage mortality determined after 10 days.
The mortality was $95,4 \%$ and $8,7 \%$ respectively. During August 1984 the experiment was repeated with 50 females from plots treated with hexachlorobutadiene and 112 females from untreated plots. The mortality after 10 days was $14,3 \%$ and $12,2 \%$ respectively.

Although females did occur 12 months after treatment with hexachlorobutadiene, their mortality in the laboratory was high indicating good control. During the second emergence of females, 24 months after treatment, poor control was obtained according to the number of females present as well as their mortality in the laboratory.

Because of the positive results obtained on adult females with hexachlorobutadiene, the effect of this treatment on cysts was again determined during August 1983, 12 months after application. A total of 44 cysts were collected from treated plots and the percentage mortality determined in the laboratory. Only $6,8 \%$ of the cysts were dead, again indicating that hexachlorobutadiene had no effect on the cysts. The high number of females that occurred after treatment with the other pesticides (Table 2) is also further proof that these pesticides had no effect on the cyst stage.

\section{Male pre-pupae and pupae}

During June 1983, 10 months after application of the chemicals, no pre-pupae or pupae were found in any of the plots treated with hexachlorobutadiene, indicating a $100 \%$ control compared to the untreated plots (Table $3)$. Complete control was also achieved in the following year, 22 months after application. During June 1985, 34 months after application, only three pre-pupae were found in one of the plots. Excellent control was therefore achieved for a period of 34 months after a single application of hexachlorobutadiene. As hexachlorobutadiene had no effect on cysts, it can be concluded that pre-pupae were killed after emergence from cysts. The other pesticides tested gave no or poor control during the first two observation periods and were therefore not evaluated again during June 1985.

\section{TABLE 3}

Mean number of pre-pupae plus pupae of Margarodes prieskaensis per plot in successive years after a single hand application with different pesticides. (Percentage control in brackets)

\begin{tabular}{|c|c|c|c|c|c|c|}
\hline \multirow{2}{*}{$\begin{array}{l}\text { Treatment } \\
\text { Control }\end{array}$} & \multicolumn{2}{|c|}{$\begin{array}{c}1983 \\
10 \text { months after } \\
\text { application }\end{array}$} & \multicolumn{2}{|c|}{$\begin{array}{c}1984 \\
22 \text { months after } \\
\text { application }\end{array}$} & \multicolumn{2}{|c|}{$\begin{array}{c}1985 \\
34 \text { months after } \\
\text { application }\end{array}$} \\
\hline & & (0) & 33 & (0) & 27 & (0) \\
\hline butadiene & & (100) & $0^{*}$ & $(100)$ & $1^{*}$ & (96) \\
\hline $\begin{array}{l}\text { Dichloro- } \\
\text { propene }\end{array}$ & & $(0)$ & 34 & $(0)$ & & - \\
\hline Aldicarb & 23 & (0) & 28 & (15) & & - \\
\hline Fenamiphos & 23 & (0) & 29 & (12) & & - \\
\hline Carbofuran & 17 & (6) & 31 & (6) & & - \\
\hline Oxamyl & 22 & (0) & 27 & (18) & & - \\
\hline
\end{tabular}

$\star$ Significantly different from the control $(\mathrm{P}=0,05)$

\section{Commercial application:}

Adult females

The effect of time of application(ta) of hexachlorobutadiene on a commercial scale on adult females is 


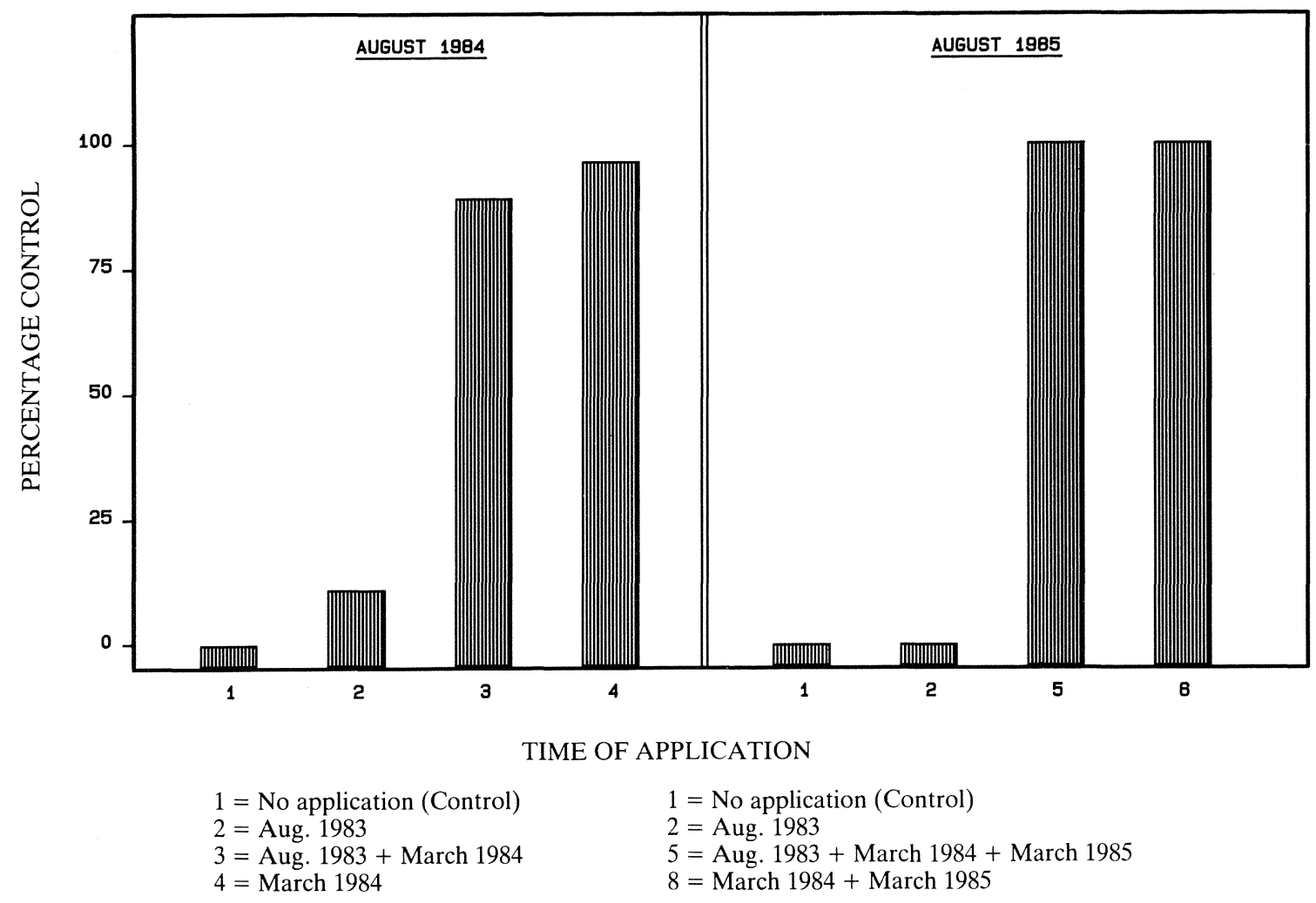

FIG. 1

Percentage control of adult females of Margarodes prieskaensis after soil treatment at different times with hexacholorobutadiene as evaluated in August 1984 and in August 1985.

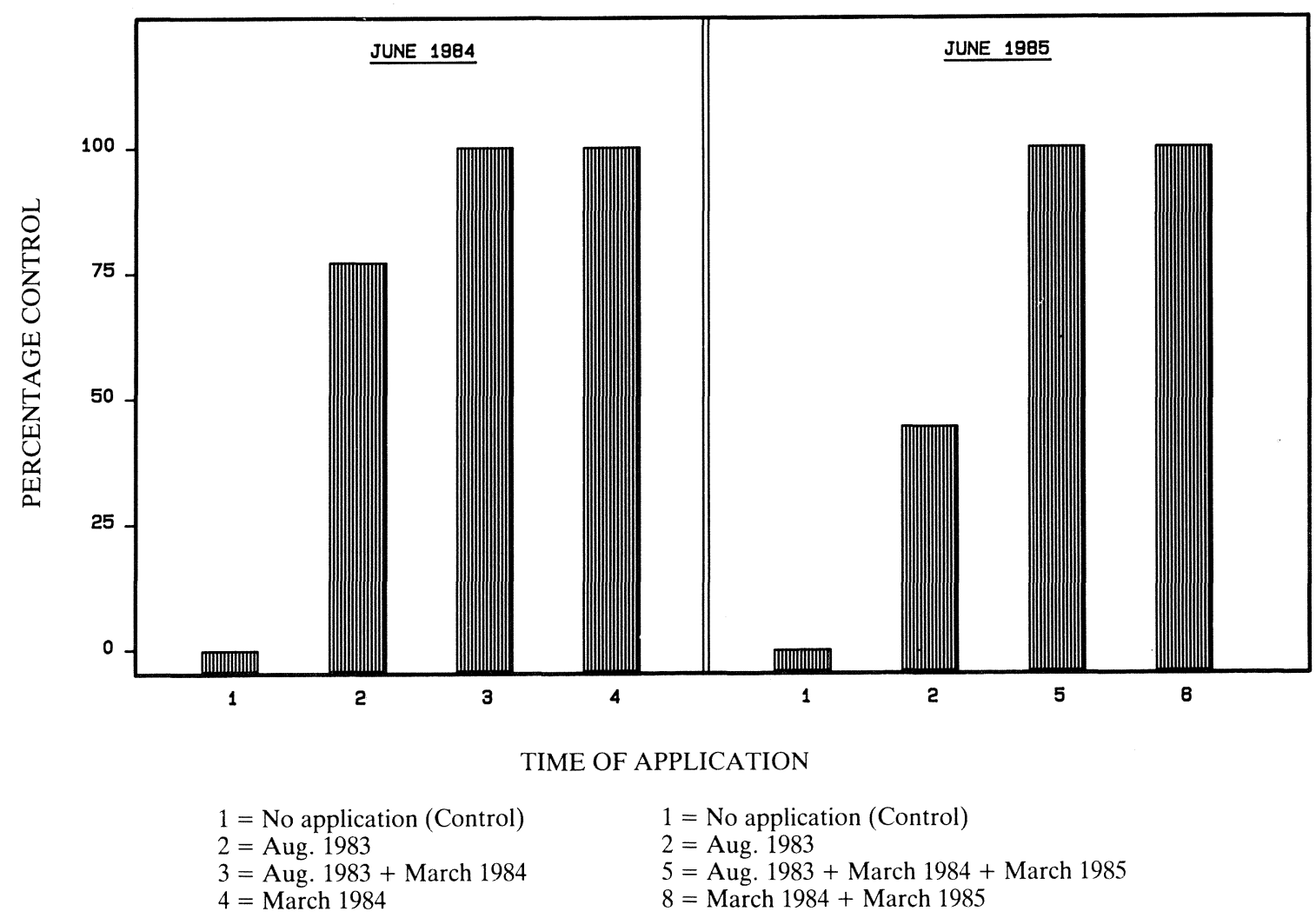

FIG. 2

Percentage control of male pre-pupae and pupae of Margarodes prieskaensis after soil treatment at different times with hexachlorobutadiene as evaluated in June 1984 and June 1985. 
shown in Figure 1. From the results obtained in August 1984 it is evident that better control was achieved with an application in March (ta4) than in August (ta2). A single application in March (ta4) gave similar control to two applications (August plus March (ta3)). Although excellent control was obtained with a single application in March, ten live females were still found compared to 198 females in the control. During August 1985, however, no females were present after the second treatment in March 1985(ta6). This indicates that $100 \%$ control can be achieved after two successive treatments during March of each year.

Adult females were collected during August 1984 from each treatment and kept in the laboratory. All females from plots treated during March were dead after three days, while $95 \%$ of those from the untreated plot were still alive. This indicates that a single treatment in March may give excellent results compared to two treatments during successive years.

With an application during August, poor control (11\%) was achieved after 12 months (August 1984 (ta2)) and no control was achieved after 24 months (August 1985 (ta2)) (Fig. 1). Of the females collected during August 1984 and kept in the laboratory, 78\% were still alive after 10 days confirming poor control of the commercial application during August. With hand application, however $65 \%$ and $48 \%$ control was achieved after 12 and 24 months respectively (Table 2). This is possibly due to the fact that hand application is more accurate in evenly applying low volumes.

\section{Pre-pupae and pupae}

The effect of time of application(ta) of hexachlorobutadiene on a commercial scale on the pre-pupae and pupae is shown in Figure 2. From the results obtained in June 1984, it is evident that better control is achieved with an application in March (ta4) than in August (ta2). A single application in March (ta4) gave the same con- trol as two applications (August plus March (ta3)). Similar results were obtained in June 1985 after a further application in March 1985.

With a single application in August 1983, only $77 \%$ and $42 \%$ control was achieved after 10 months (June 1984 (ta2)) and 22 months (June 1985 (ta2)) respectively. With hand application, however, $100 \%$ control was achieved up to 22 months after application (Table 3 ). As mentioned previously, this is possibly because hand application is more accurate than application on a commercial scale.

\section{CONCLUSIONS}

The results indicate that hexachlorobutadiene is effective for the control of Margarodes prieskaensis when applied at a rate of $12 \mathrm{ml} / \mathrm{m}^{2}$. Although no effect was evident on the cyst stage, excellent control of adult females and male pre-pupae and pupae was achieved. During the cyst stage the nymph is covered with thick layers of hard waxlike material which presumably affords protection of the nymph against soil fumigants.

With a commercial application of hexachlorobutadiene improved control was obtained with an application in March compared to August. Presumably this is because in the case of a March application a one and a three month residual effect is needed for the control of pupae and females respectively, whilst an August application requires an 8 and a 10 month residual effect for the same purpose.

It is recommended that the application of hexachlorobutadiene should be made during two consecutive years based on the fact that not all cysts develop into male pre-pupae and adult females annually and the exact residual period of hexachlorobutadiene is not known.

The results further show that no or poor control of $M$. prieskaensis was obtained with dichloropropene, aldicarb, fenamiphos, carbofuran and oxamyl.

\section{LITERATURE CITED}

BARNES, M.M., ASCH, C.R. \& DEAL, A.S., 1954. Ground pearls on grape roots. Californian Agriculture 8 (12), 5, 10.

DE KLERK, C.A, 1975. Margarodes - 'n belangrike insekteplaag van wingerd. Wynboer 521, 59-62.

DE KLERK, C.A., 1983. Two new species of Margarodes (Homoptera: Coccoidea: Margarodidae) from South Africa. Phytophylactica 15, 85-93.

DE KLERK, C.A., 1985. Occurrence of South Africa species of $M a$ rgarodes Guilding (Homoptera: Coccoidea: Margarodidae) with special reference to vine infesting species. Phytophylactica 17, 215-216.

DE KLERK, C.A., BEN-DOV, Y. \& GILIOMEE, J.H., 1982a. Redescriptions of four vine infesting species of Margarodes Guilding (Homoptera: Coccoidea: Margarodidae) from South Africa. Phytophylactica 14, 61-76.

DE KLERK, C.A., BEN-DOV, Y. \& GILIOMEE, J.H., 1982b. Redescriptions of three Margarodes Guilding species (Homoptera: Coccoidea: Margarodidae) found on grasses in South Africa. Phytophylactica 14, 77-83.

DE KLERK, C.A., BEN-DOV, Y. \& GILIOMEE, J.H., 1983. General morphology of South African species of Margarodes
Guilding (Homoptera: Coccoidea: Margarodidae) with keys to nymphs and adult females. Phytophylactica 15, 133-144.

DE KLERK, C.A., GILIOMEE, J.H. \& BEN-DOV, Y., 1980. Biology of Margarodes capensis Giard (Homoptera: Coccoidea: Margarodidae) under laboratory and controlled conditions in South Africa. Phytophylactica 12, 147-156.

DE KLERK, C.A., GILIOMEE, J.H. \& BEN-DOV, Y., 1982. Biology of Margarodes capensis Giard (Homoptera: Coccoidea: Margarodidae) under field conditions in South Africa. Phytophylactica 14, 85-93.

DU TOIT, G.D.G., 1975. Notes on the biology and behaviour of Sphaeraspis prieskaensis Jak. (Hemiptera: Coccoidea). A pest on grape-vine roots. In Proc. Ist. Congr. Ent. Soc. S. Afr. (1975), 255-257.

FAURÉ, G.O. \& PINTO, J.C., 1959. Pests of grape-vine in Chile. Plant Protection Bulletin F.A.O. 7, 73-77.

JAKUBSKI, A.W., 1965. A critical revision of the families Margarodidae and Termitococcidae (Hemiptera, Coccoidea). British Museum (nat. Hist.) London, $187 \mathrm{pp.}$

ZEEMAN, A.S., 1981. Plantwydtes. In Wingerdbou in Suid-Afrika. J. Burger \& J. Deist (editors), pp 179-200. V.O.R.I., Private Bag X5026, 7600 Stellenbosch. 